\title{
Whole Genome Analyses of Treponemes: New Targets for Strain- and Subspecies- Specific Molecular Diagnostics
}

\author{
David Šmajsํㅜ, Lenka Mikalová1, Darina Čejková1, \\ Michal Strouhal ${ }^{1}$, Marie Zobaníková1, Petra Pospíšilová1, \\ Steven J. Norris ${ }^{2}$ and George M. Weinstock ${ }^{3}$ \\ ${ }^{1}$ Masaryk University Czech Republic \\ 2 University of Texas-Houston Medical School \\ ${ }^{3}$ Washington University School of Medicine
}

USA

\section{Introduction}

The genus Treponema comprises several human uncultivable pathogens including Treponema pallidum subspecies pallidum (TPA, the causative agent of the sexually transmitted syphilis), Treponema pallidum subspecies pertenue (TPE, causative agent of yaws), Treponema pallidum subspecies endemicum (TEN, causing endemic syphilis), and Treponema carateum causing pinta. Additionally, the rabbit pathogen Treponema paraluiscuniculi (TPC) is very similar to syphilis treponeme but is not pathogenic to humans. Other pathogenic treponemes (e.g. Treponema denticola and $T$. vincentii) differ from the others by having considerably larger genomes (MacDougall \& Girons, 1995; Seshadri et al., 2004). Moreover, these treponemes can be cultivated under in vitro conditions. The infections caused by human uncultivable pathogenic treponemes can be classified according to their invasivity, from the most invasive bacterium causing venereal syphilis to Treponema carateum (pinta), which is a noninvasive spirochete causing local dermal lesions (Antal et al., 2002). Strains of non-venereal treponemes including Treponema pallidum subspecies pertenue and endemicum are considered moderately invasive.

The whole genome analyses of treponemes started with the completion of the whole genome sequence of T. pallidum, by Nichols strain in 1998 (Fraser et al., 1998). Since then, a number of genome studies have been performed (e.g. Brinkmann et al., 2006; Giacani et al., 2010; Harper et al., 2008a; Matějková et al., 2008; McKevitt et al., 2003; McKevitt et al., 2005; Mikalová et al., 2010; Šmajs et al., 2005; Strouhal et al., 2007; Titz et al., 2008). The genomic data has provided new opportunities to study pathogenic treponemes and increase our understanding of these unique pathogens.

Serological tests are considered standard laboratory methods for the diagnosis of syphilis since direct diagnostic methods are limited by the fact that the T. pallidum treponemes cannot be cultured continuously under in vitro conditions. The rabbit infectivity test (RIT) is the gold standard for demonstrating T. pallidum infection, but is impractical for clinical use 
because of high costs and delayed test results. Microscopic identification of treponemes in clinical samples, particularly in combination with direct fluorescent antibody tests using anti-T. pallidum antibodies, is highly specific for treponemal infections; however, it does not distinguish between pathogenic treponemal species and requires technical expertise that is not commonly available in a clinical setting. Observed clinical manifestations, history, and serology have thus been the standard procedure for diagnosis of treponemal infections for the past century. However, the available serologic tests have several important limitations: i) the antibody response to treponemal infections is often not detectable during the first 1-3 weeks of infection, ii) routine treponemal tests for syphilis, which detect IgG antibodies, will be positive if the patient has a previous history of syphilitic infections, iii) diagnosis of congenital syphilis can be confused by transferred antibodies from the mother, and iv) serological tests in patients with a risk of endemic treponematoses cannot distinguish between these infections and syphilis.

In the last years, there has been an increasing effort to apply PCR techniques for direct diagnosis of syphilis (for review see Šmajs et al., 2006). PCR detection of treponemal DNA is a direct method with sensitivity as low as a few copies of the treponemal chromosome per PCR reaction. Moreover, PCR detection of treponemal 16S rRNA, present in many copies per single treponemal genome increases the sensitivity to $10^{-2}-10^{-3}$ genome equivalents (Centurion-Lara et al., 1997). However, the relatively low numbers of treponemes in whole blood put limitations on PCR diagnosis of syphilis from blood samples.

\section{Whole genome analyses of uncultivable treponemes}

\subsection{Whole genome fingerprinting}

The genomes of nine uncultivable treponemes including T. p. pallidum strains (Nichols, SS14, DAL-1 and Mexico A), T. p. pertenue strains (Samoa D, CDC-2 and Gauthier), Treponema paraluiscuniculi Cuniculi A strain, and the Fribourg-Blanc simian isolate, were studied using the whole genome fingerprinting technique (WGF, Mikalová et al., 2010; Strouhal et al., 2007; Weinstock et al., 2000). More than 130 individual amplicons covering the entire genome were digested with a set of several restriction endonucleases and the resulting restriction fragments were visualized using gel electrophoresis. WGF was used to estimate the genome size, genome structure and the sequentially diverse chromosomal regions (Table 1).

The observed differences, in the presence of restriction target sites, grouped T. p. pallidum strains into a separate cluster compared to T. p. pertenue strains. The Fribourg-Blanc isolate, although more distantly separated, was clustered with TPE strains (Fig. 1). Analysis of the tprC and tprI gene phylogeny (Gray et al., 2006) revealed similar close relationships between the Fribourg-Blanc treponemes and T. p. pertenue strains. The Fribourg-Blanc isolate is infectious to humans and is able to cause symptoms of yaws (Smith, 1971; Smith et al., 1971). Although the genome analysis of T. pallidum ssp. endemicum strain Bosnia A (Grin, 1952) has not yet been completed, the preliminary analysis of more than a quarter of the genome $(25.6 \%)$ has revealed a relatedness among the TEN Bosnia A strain, TPE strains, and the Fribourg-Blanc treponeme (Fig. 1, panel B). The observed relatedness between the TPE and the Fribourg-Blanc strains suggests a possible common origin of these strains and potentially indicates treponemal strain transmission between humans and African primates. Since yaws and simian treponemal infections occur in overlapping geographic territories, human treponemal pathogens may have originated in Africa (Livingstone, 1991). The observed restriction target site diversity among TPA strains indicates the presence of two 
separated groups (the Nichols group and the SS14 group) of TPA strains that coexist in the human population.

\begin{tabular}{|c|c|c|c|c|c|}
\hline $\begin{array}{l}\text { Strain } \\
\text { name }\end{array}$ & $\begin{array}{c}\text { Species/ } \\
\text { Subspecies* }\end{array}$ & $\begin{array}{l}\text { Place and } \\
\text { year of } \\
\text { isolation }\end{array}$ & $\begin{array}{l}\text { Revealed } \\
\text { genome } \\
\text { size }(\mathrm{kb})\end{array}$ & $\begin{array}{l}\text { Revealed genome } \\
\text { sequence identity } \\
\text { with Nichols (\%) }\end{array}$ & Reference \\
\hline Nichols & TPA & $\begin{array}{l}\text { Washington, } \\
\text { DC; } 1912\end{array}$ & 1139.6† & 100 & $\begin{array}{c}\text { Mikalová et al., } \\
\text { 2010; Nichols \& } \\
\text { Hough, } 1913\end{array}$ \\
\hline DAL-1 & TPA & Dallas; 1991 & 1139.9 & 99.98 & $\begin{array}{c}\text { Mikalová et al., } \\
\text { 2010; Wendel et al., } \\
1991\end{array}$ \\
\hline SS14 & TPA & Atlanta; 1977 & 1139.5 & 99.92 & $\begin{array}{l}\text { Mikalová et al., } \\
\text { 2010; Stamm et al., } \\
1983\end{array}$ \\
\hline Mexico A & TPA & Mexico; 1953 & 1140.0 & 99.93 & $\begin{array}{c}\text { Turner \& } \\
\text { Hollander, 1957; } \\
\text { Mikalová et al., } \\
2010\end{array}$ \\
\hline Samoa D & TPE & $\begin{array}{c}\text { Western } \\
\text { Samoa; } 1953\end{array}$ & 1139.3 & 99.64 & $\begin{array}{c}\text { Turner \& } \\
\text { Hollander, 1957; } \\
\text { Mikalová et al., } \\
2010\end{array}$ \\
\hline CDC-2 & TPE & $\begin{array}{c}\text { Akorabo, } \\
\text { Ghana; } 1980\end{array}$ & 1139.7 & 99.63 & $\begin{array}{c}\text { Liska et al., 1982; } \\
\text { Mikalová et al., } \\
2010\end{array}$ \\
\hline Gauthier & TPE & Congo; 1960 & 1139.4 & 99.64 & $\begin{array}{c}\text { Gastinel et al., 1963; } \\
\text { Mikalová et al., } \\
2010\end{array}$ \\
\hline $\begin{array}{l}\text { Fribourg- } \\
\text { Blanc }\end{array}$ & ? & Guinea; 1966 & 1140.4 & 99.57 & $\begin{array}{l}\text { Fribourg-Blanc \& } \\
\text { Mollaret, 1969; } \\
\text { Mikalová et al., } \\
2010\end{array}$ \\
\hline Cuniculi A & $\mathrm{TPC}$ & $?$ & 1133.4 & 98.21 & Strouhal et al., 2007 \\
\hline
\end{tabular}

${ }^{*} \mathrm{TPA}=\mathrm{T}$. pallidum subsp. pallidum; TPE $=\mathrm{T}$. pallidum subsp. pertenue; $\mathrm{TPC}=\mathrm{T}$. paraluiscuniculi. †The $1.2 \mathrm{~kb}$ tprK-like insertion in part of Nichols population (Šmajs et al., 2002) was added to the previously published genome sequence (Fraser et al., 1998).

Table 1. Genome size and revealed genome sequence identity with the Nichols genome of $T$. p. pallidum, T. p. pertenue, T. paraluiscuniculi and the Fribourg-Blanc strains.

The WGF technique also identified genomic regions showing variability in most investigated strains including the intergenic region between genes TP0126 and TP0127, and in the arp, TP0470, and TP0967 genes. Among the investigated TPA and TPE genomes, the tprK-like sequence inserted between the TP0126 and TP0127 genes was found in three different versions (Mikalová et al., 2010). In the Nichols genome, this insertion was found only in part of the treponemal population (Šmajs et al., 2002). With regard to the arp gene 
(Pillay et al., 1998), a variable number of tandem repetitions were found in the tested genomes. Based on amino acid variations, previously published papers (Harper et al., 2008b; Liu et al., 2007) classified the TPA and TPE Arp repeat motifs into 4 types (I, II, III, II/III), and the variability in repeat sequence types correlated with the sexual transmission strategy (Harper et al., 2008b). The differences among tested strains were also found in a number of $24 \mathrm{bp}$ tandem repeats of TP0470, a gene encoding a hypothetical protein, and in indels present in the hypothetical TP0967 gene (Mikalová et al., 2010). As with the tprK-like insertion between the TP0126 and TP0127 genes, the number of 24 bp repetitions in TP0470 was reported to vary within individual bacterial isolates (Marra et al., 2010).

A

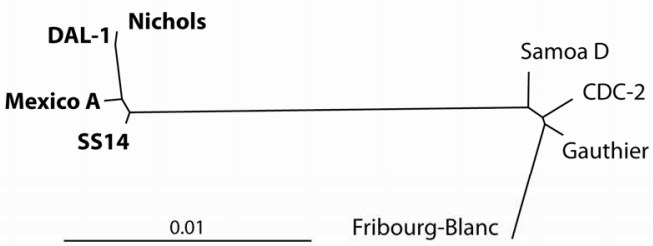

B

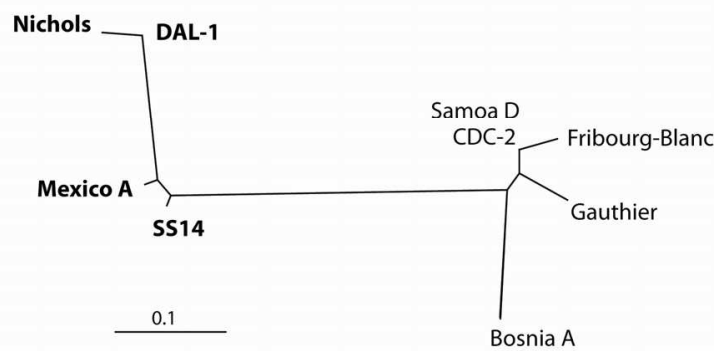

Fig. 1. Unrooted trees constructed from restriction target site data of the analyzed TPA and TPE genomes. Panel A: unrooted tree constructed from whole genome analyses. The Fribourg-Blanc isolate clusters with TPE strains. Panel B: unrooted tree constructed from $25.6 \%$ of the tested genomes. The Bosnia A strain clusters with TPE genomes, indicating a close relationship between this T. pallidum ssp. endemicum strain and TPE strains. The bar scale corresponds to 0.01 and 0.1 restriction target site (RTS) changes per RTS, respectively. TPA strains are shown in bold.

\subsection{Whole genome sequencing}

Historically, syphilis and yaws treponemes were considered to be separate species (based on differences in clinical manifestations of the corresponding diseases), but since 1984 they have been classified as subspecies (Smibert, 1984) based on DNA hybridization experiments (Miao and Fieldsteel, 1980).

The WGF technique revealed high sequence relatedness among all investigated genomes, with the most divergent, T. paraluiscuniculi, genome differing in less than $2 \%$ of the genome sequence (Strouhal et al., 2007). These data indicated that complete, high-quality sequences were required for treponeme genome comparisons. The list of sequenced treponemal genomes and the status of sequencing is shown in Table 2. 
With the exception of the Nichols and Chicago genomes, whole genome DNA sequencing has been performed using a combination of several approaches including comparative genome sequencing (CGS, Matějková et al., 2008), 454 pyrosequencing (Margulies et al., 2005) and the Solexa/Illumina method (Bennett, 2004). Isolated genomic DNA of most of the sequenced strains was amplified before genomic DNA sequencing. All discrepancies in CGS, 454 and Solexa/Illumina sequences were resequenced, using the dideoxyterminator sequencing method, until a final consensus sequence was obtained.

\begin{tabular}{|c|c|c|c|}
\hline $\begin{array}{l}\text { Treponemal } \\
\text { strain }\end{array}$ & Treponeme & Sequencing method & $\begin{array}{l}\text { Reference/GenBank accession } \\
\text { number }\end{array}$ \\
\hline Nichols & TPA & DDT & Fraser et al., 1998 \\
\hline SS14 & TPA & CGS & Matějková et al., 2008 \\
\hline Chicago & TPA & Illumina & Giacani et al., 2010 \\
\hline DAL-1 & TPA & 454, Illumina & unpublished \\
\hline Mexico A & TPA & Illumina & unpublished \\
\hline Samoa D & TPE & CGS, 454, Illumina & СР002374 \\
\hline CDC-2 & TPE & 454, Illumina & СР002375 \\
\hline Gauthier & TPE & 454, Illumina & СР002376 \\
\hline $\begin{array}{l}\text { Fribourg- } \\
\text { Blanc }\end{array}$ & ? & 454, Illumina & unpublished \\
\hline Cuniculi A & ТРC & CGS, 454, Illumina & СР002103 \\
\hline Bosnia A & TEN & 454, Illumina & unpublished \\
\hline
\end{tabular}

Table 2. Whole genome sequencing of uncultivable treponemal strains

Sequencing of the T. paraluiscuniculi genome revealed $99.16 \%$ sequence identity (Šmajs et al., 2011) of the conserved regions of the Nichols and Cuniculi A genomes. The identity between TPA and TPE genomes, greater than $99.8 \%$, was found during sequencing of three TPE genomes (Čejková et al., unpublished data). In all sequenced genomes, no major genome rearrangements were found. Despite the different clinical manifestations and host specificities, a nearly identical gene order was found in TPA, TPE, and T. paraluiscuniculi strains, further establishing the close genetic relationship between these treponemal pathogens. The accuracy of genome assemblies and the sequencing error rate were estimated using the WGF approach and revealed high quality genome sequences with an error rate less than $10^{-4}$. All investigated TPE strains were very similar in genome size with only $414 \mathrm{bp}$ difference between the largest, CDC-2, and the smallest, Samoa D, genome. Nucleotide diversity $(\pi)$ among sequenced TPE genomes was quite low (0.00032). In contrast, the nucleotide divergence $\left(d_{A}\right)$ between TPA and TPE genomes was 3.6 - 4.6 times higher than the observed nucleotide diversity among each subspecies. These data indicate a significant evolutionary relationship between yaws and syphilis strains. Sequencing of additional TPA and TPE strains in the future will result in decreased numbers of genetic differences relevant to clinical manifestations of yaws and syphilis treponemes.

Altogether, 13 pseudogenes were found in the TPE genomes. In addition to pseudogenes, the genetic changes were analyzed in 970 similarly annotated protein-coding genes in both TPE and TPA strains. Compared to TPA strains, $70.4 \%$ of TPE genes encoded either identical proteins or identical proteins with strain specific differences; 194 (19.7\%) genes encoded proteins with 1 amino acid substitution found in all tested TPE strains, 63 (6.4\%) genes 
encoded proteins with 2 to 5 amino acid changes, and only 34 (3.5\%) genes encoded proteins with 6 or more amino acid replacements or other major protein changes.

Major sequence changes between TPA and TPE treponemes were found in the sequence for ethanolaminephosphotransferase, which is a pseudogene in TPE strains (TPE_0671), and in additional 12 genes with predicted functions including $8 \mathrm{tpr}$ genes. The Tpr proteins are heterogenous proteins considered as potential virulence factors involved in pathogenesis and/or immune evasion (Giacani et al., 2004; Gray et al., 2006), and in inducing an antibody response during treponemal infection (Centurion-Lara et al., 1999, 2000a, 2000b). Other differences between TPA and TPE involved a Mcp (methyl-accepting chemotaxis protein, TPE_0488), three treponemal antigens (TPE_0136; (Brinkman et al., 2008), the Tp92 - outer membrane protein (TPE_0326; Cameron et al., 2000), the Arp protein (TPE_0433, Pillay et al., 1998)) and an elongated RecQ protein (TPE_0103) (Čejková et al., unpublished results).

\section{Targets for TPA strain-specific molecular diagnostics}

\subsection{Multilocus analyses of treponemal strains}

The whole genome analyses of treponemal genomes revealed chromosomal regions with accumulated genetic diversity between TPA and TPE strains (Fig. 2).

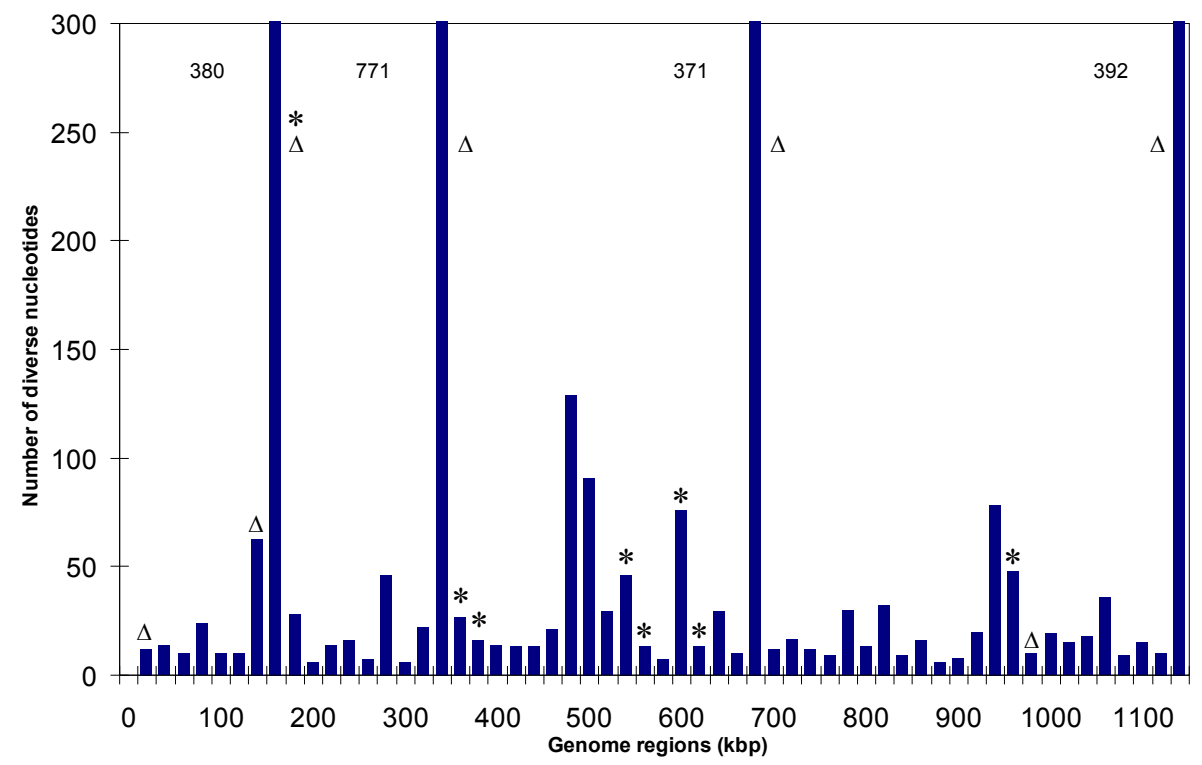

Fig. 2. Plot of numbers of nucleotide changes in $20 \mathrm{~kb}$ intervals between TPA and TPE strains along the treponemal chromosome. The exact number of nucleotide changes in the four most diverse regions is shown next to each column. Positions of selected chromosomal loci (see Table 3 and 4) are shown by asterisks. Positions of tpr genes in the treponemal genomes are shown with triangles $(\Delta)$.

In these regions, we determined the most genetically diverse genes and analyzed them in a set of TPA strains. In addition to four TPA strains (Nichols, SS14, DAL-1 and Mexico A), 
TPA strains Grady (Atlanta, 1980), MN-3 (Minnesota, unknown), Philadelphia-1 (Philadelphia, 1988), Philadelphia-2 (Philadelphia, unknown), Bal-73-01 (Baltimore, 1973) were analyzed. All these strains were kindly provided by D. L. Cox, CDC, Atlanta, GA. The results of this analysis are summarized in the Tables 3 and 4 . The greatest observed nucleotide difference was found in the TP0136 locus, followed by TP0548, TP0326 and TP0488. Interestingly, all investigated strains split into two subclusters containing either the Nichols or the SS14 strain (see Fig. 3).

\begin{tabular}{lcccc}
\hline \multicolumn{5}{c}{$\begin{array}{c}\text { Differences in the nucleotide sequences, } \%, ~ \\
\text { (difference in number of nt) }\end{array}$} \\
\hline Strain & TP0136 & TP0326 & TP0488 & TP0548 \\
Nichols & 0 & 0 & 0 & 0 \\
SS14 & 4.4 & 0.5 & 0.2 & 3.4 \\
Mexico A & 4.5 & 0.4 & 1.1 & 3.7 \\
DAL-1 & 4.0 & $0(0 \mathrm{nt})$ & $0(0 \mathrm{nt})$ & $0(0 \mathrm{nt})$ \\
Grady & 4.4 & 0.5 & 0.1 & 3.4 \\
MN-3 & 0.1 & $0(1 \mathrm{nt})$ & 0.1 & 0.8 \\
Philadelphia 1 & 4.4 & 0.5 & 0.1 & 3.4 \\
Philadelphia 2 & 0.1 & $0(1 \mathrm{nt})$ & 0.1 & 0.8 \\
Bal-73-01 & $0(0 \mathrm{nt})$ & $0(0 \mathrm{nt})$ & $0(1 \mathrm{nt})$ & $0(0 \mathrm{nt})$ \\
\hline
\end{tabular}

Table 3. Analysis of 4 chromosomal loci as potential targets for PCR detection and typing of clinical treponemal samples. The table shows the percentage of nucleotide differences compared to sequences present in the Nichols genome (Fraser et al., 1998).

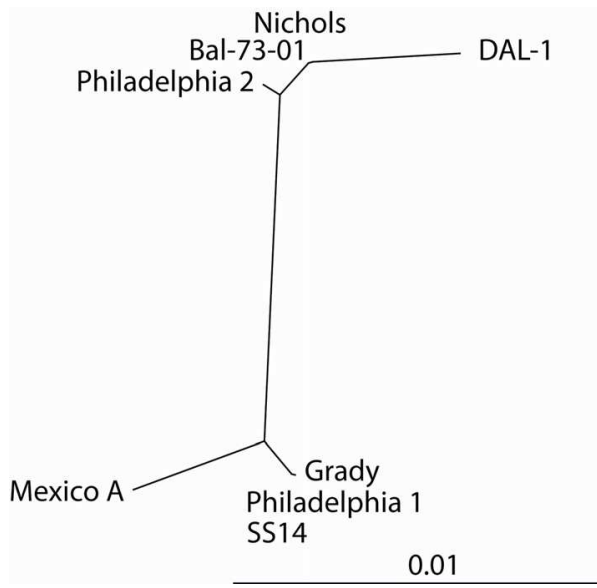

Fig. 3. The unrooted tree constructed from the nucleotide region resulting from concatenation of TP0136, TP0326, TP0488, and TP0548 loci sequenced in several TPA strains (of lengths ranging from 8342 to 8412 nucleotides). The bar scale corresponds to $0.01 \mathrm{nt}$ changes per site. Please note that the TPA strains subcluster into two groups, one associated with the Nichols and the second associated with the SS14 strain. 
In addition to TP0136, TP0548, TP0326 and TP0488 loci, we also tested other candidate chromosomal regions including TP0346, TP0515, TP0558, and TP0868 genes. The observed nucleotide diversity of these loci is shown in Table 4. The nucleotide diversity was considerably smaller among the latter group of genes (TP0346, TP0515, TP0558, and TP0868) indicating that their potential for testing of clinical TPA samples is lower than that of loci shown in Table 3. As in the previous case, Nichols-like strains were extremely similar to each other and distinct from SS14-like strains, reflecting different evolutionary relationships between these strains.

\begin{tabular}{lcccc}
\hline \multicolumn{5}{c}{ Number of detected nucleotide changes } \\
\hline Strain & TP0346 & TP0515 & TP0558 & TP0868 \\
Nichols & 0 & 0 & & \\
SS14 & nd* & 10 & 0 & 0 \\
Mexico A & nd & nd & nd & 9 \\
DAL-1 & 0 & 0 & 0 & 2 \\
Grady & 2 & nd & 5 & 0 \\
MN-3 & 0 & nd & nd & 9 \\
Philadelphia 1 & 2 & 10 & 5 & 0 \\
Philadelphia 2 & nd & nd & nd & 2 \\
Bal-73-01 & 0 & 0 & 0 & 0 \\
\hline
\end{tabular}

*nd, not determined

Table 4. Analysis of chromosomal loci as potential targets for PCR detection and typing of treponemes. The table shows the number of detected nucleotide changes compared to sequences present in the Nichols genome (Fraser et al., 1998).

\subsection{PCR analyses of clinical samples}

Chromosomal genes including TP0136, TP0326, TP0488, TP0548, and TP0868, previously sequenced in TPA type strains, were used as DNA amplification targets from clinical samples containing treponemal DNA. The tested clinical samples were collected in the Czech Republic between years 2004 and 2010. The detected numbers of nucleotide changes were considerably lower than among the tested TPA type strains, indicating a genetic homogeneity of syphilis-causing strains in the Czech Republic. At locus TP0868, no diversity was observed among 5 tested clinical samples (see Table 5) and all TP0868 gene sequences were identical to the SS14 sequence. Interestingly, only strains identical or very similar to the SS14 strain were found among all investigated clinical strains (taken from 91 patients with sequenced treponemal DNA; unpublished results). Although not all gene sequences in the investigated strains were determined, the number of identified unique sequences (shown as unique a - d; Table 5) correlated with the number of nucleotide changes observed in Table 3, indicating that the most variable chromosomal regions identified during whole genome analyses were also the most variable among sequentially related clinical strains, i.e. causing syphilis, from particular geographic areas. 


\begin{tabular}{|c|c|c|c|c|c|c|c|c|}
\hline $\begin{array}{l}\text { Clinical } \\
\text { sample }\end{array}$ & ТP0136 & ТР0548 & ТР0326 & ТР0488 & ТР0868 & $23 \mathrm{~S}$ rDNA & $\begin{array}{l}\text { No. of } \\
\text { repetitions in } \\
\text { the } \operatorname{arp} \text { gene }\end{array}$ & $\begin{array}{c}t p r \mathrm{EGJ} \\
\text { genes }\end{array}$ \\
\hline D-151 & $\begin{array}{c}\text { unique } \\
\mathrm{a}^{*}\end{array}$ & SS14-like & $\mathrm{nd}^{* *}$ & nd & $\begin{array}{l}\text { SS14- } \\
\text { like }\end{array}$ & sensitive $^{* * *}$ & 8 & $d^{* * * *}$ \\
\hline $3 Z$ & unique $b$ & SS14-like & nd & nd & nd & sensitive & 14 & $\mathrm{~d}$ \\
\hline $2 \mathrm{~K}$ & SS14-like & unique a & nd & nd & nd & A2058G & 14 & $\mathrm{~d}$ \\
\hline G-269 & SS14-like & unique $b$ & nd & nd & $\begin{array}{l}\text { SS14- } \\
\text { like }\end{array}$ & sensitive & 14 & $\mathrm{p}$ \\
\hline RL73 & nd & unique c & nd & nd & nd & A2059G & nd & $\mathrm{d}$ \\
\hline $1 Z$ & nd & unique $\mathrm{d}$ & nd & nd & nd & A2058G & 14 & $\mathrm{~d}$ \\
\hline $50 \mathrm{AZ}$ & SS14-like & nd & \multicolumn{2}{|c|}{ unique a unique a } & $\begin{array}{l}\text { SS14- } \\
\text { like }\end{array}$ & A2059G & 15 & d \\
\hline 11379 & SS14-like & nd & \multicolumn{2}{|c|}{ SS14-like unique a } & $\begin{array}{l}\text { SS14- } \\
\text { like }\end{array}$ & sensitive & 11 & $\mathrm{~d}$ \\
\hline $24 \mathrm{~K}$ & \multicolumn{2}{|c|}{ SS14-like SS14-like } & nd & nd & nd & sensitive & 14 & d \\
\hline $40 \mathrm{~K}$ & \multicolumn{2}{|c|}{ SS14-like SS14-like } & nd & nd & nd & A2058G & 14 & d \\
\hline 8284 & \multicolumn{2}{|c|}{ SS14-like SS14-like } & nd & nd & nd & A2059G & 15 & d \\
\hline $24 \mathrm{AZ}$ & \multicolumn{2}{|c|}{ SS14-like SS14-like } & nd & nd & nd & A2059G & 12 & d \\
\hline $37 \mathrm{~K}$ & nd & nd & nd & nd & nd & A2058G & 12 & $\mathrm{~d}$ \\
\hline $\begin{array}{c}\text { No. of } \\
\text { different } \\
\text { genotypes }\end{array}$ & 3 & 5 & 2 & 1 & 1 & 3 & 5 & 2 \\
\hline
\end{tabular}

*unique a, sequencing of this locus revealed a sequence different from the SS14 sequence. Different sequences at a particular locus are denoted with letters a-d.

**nd, not determined

***sensitive, unmutated $23 \mathrm{~S}$ rRNA resulting in susceptibility of TPA strains to macrolide antibiotics; A2058G or A2059G mutations result in resistance to macrolides.

${ }^{* * * *} \mathrm{~d}$, restriction patterns according to Pillay et al., (1998)

Table 5. Analysis of chromosomal loci as potential targets for PCR detection and typing of treponemes. Data for 13 selected samples isolated between the 2004 and 2010 from patients in Czech Republic are shown. 
The data shown in Table 5 indicate numbers of different genotypes identified by sequencing analysis of several treponemal chromosomal loci. The greatest numbers of genotypes were found for the locus TP0548 (5) and for genetic variants detected by amplification of the arp gene (5). The use of the TP0548 locus in molecular typing of syphilis was first described by Flasarová et al. (2006) and this locus was recently incorporated to the enhanced molecular typing system of Treponema pallidum (Marra et al., 2010). Analysis of TP0136 revealed 3 genotypes. Although the loci TP0326, TP0488 and TP0868 were sequenced in only a few of the presented isolates, one to two different genotypes were identified. Moreover, the unique sequences for the investigated TP loci appear to vary independently with each other and also vary independently with the number of repetitions in the arp gene and restriction profile of tprEGJ genes. This finding indicates the potential of using the above stated chromosomal loci in a detailed genetic identification of clinical samples. Although the typing of $23 \mathrm{~S}$ rDNA locus revealed three genotypes, one encoding sensitivity to macrolide antibiotics and two coding for macrolide resistance (A2058G and A2059G mutations, respectively; Lukehart et al., 2004; Matějková et al., 2009; Stamm \& Bergen, 2000), their use in molecular typing is probably limited by the fact that these mutations can be selected by use of macrolide antibiotics in a population. In the Czech Republic, more than $35 \%$ of clinical samples were found to contain a mutation encoding resistance to macrolide antibiotics (Flasarová et al., unpublished results). In contrast, screening of 23S rDNA for A2058G in syphilitic samples taken from patients in Madagascar revealed no such mutation in 141 samples (Van Damme et al., 2009). The recently improved CDC typing system (Marra et al., 2010) relies on detection of the number of repetitions in the arp gene, on amplification and restriction digest analysis of $t p r E G J$ genes and on sequencing of a part of the TP0548 gene.

\section{Chromosomal targets for detection of non-TPA strains}

\subsection{Chromosomal targets for detection of TPE strains}

Endemic treponematoses (caused by T. pallidum subsp. pertenue, T. pallidum subsp. endemicum and T. carateum) are estimated to currently affect more than 2.5 million people worldwide (Antal et al., 2002). In the previous century, the number of yaws cases decreased from 50 million to a few million. In recent years, yaws has re-emerged in several rural populations in Africa, Asia and South America and a new effort to eradicate this disease has recently been undertaken (Asiedu et al., 2008). Since single-dose penicillin is both cheap and available and no other disease reservoirs (besides humans and primates) are known, the chances for yaws eradication are relatively good. Molecular diagnosis of yaws treponemes in this situation is of fundamental importance. In the last two decades, several subtle genetic differences between TPA and TPE strains were published (Walker et al., 1995; CenturionLara et al., 1998; Centurion-Lara et al., 2006). The most prominent indels common for all investigated TPE strains are shown in Table 6.

The regions listed in Table 6 and several additional regions (Mikalová et al., 2010) need to be tested for other TPE strains before selecting the most suitable target for a molecular diagnosis of the yaws causing strains. Interestingly, all these indels are also found in the Fribourg-Blanc genome. However, the Fribourg-Blanc isolate can be differentiated based on the presence of specific indels (Mikalová et al., 2010) as well as other individual TPE strains (Mikalová et al., 2010). 


\begin{tabular}{lll}
\hline $\begin{array}{l}\text { Intergenic region (IGR) } \\
\text { or gene(s) }\end{array}$ & Detected indel (bp) & GenBank accession no. \\
\hline & & HM165228 Samoa D \\
TP0266 & deletion (33 bp) & HM165229 Gauthier \\
$(278334-278366)^{*}$ & & HM165230 CDC-2 \\
& & HM165231 Fribourg-Blanc \\
& & HM585230 Samoa D \\
TP0316 & insertion (635 bp) & HM585231 Gauthier \\
$(331265-331266)$ & & HM585232 CDC-2 \\
& & HM585233 Fribourg-Blanc \\
& & HM245777 Samoa D \\
IGR TP0548-TP0549 & insertion (52 bp) & HM243496 Gauthier \\
$(593023-593024)$ & & HM243495 CDC-2 \\
& & HM623430 Samoa D \\
& & HM585235 Gauthier \\
TP1030-TP1031 & deletion (377 bp) & HM585236 CDC-2 \\
$(1123987-1124363)$ & & HM585254 Fribourg-Blanc \\
& &
\end{tabular}

*The coordinates refer to the published Nichols genome (Fraser et al., 1998)

Table 6. Most prominent indels identified in all investigated TPE strains (Samoa D, CDC-2, and Gauthier). All these changes were also found in the Fribourg-Blanc genome (Mikalová et al., 2010).

\subsection{Chromosomal targets for detection of TEN strains}

The ongoing whole genome sequencing project of T. p. endemicum strain Bosnia A has already identified indels in at least 4 regions (ranging between 13 and $\sim 60 \mathrm{bp}$ ), which can be used to differentiate the bejel treponeme from both the T. p. pallidum and T. p. pertenue strains (Table 7).

\begin{tabular}{lll}
\hline $\begin{array}{l}\text { Intergenic region } \\
\text { (IGR) or gene(s) }\end{array}$ & Detected indel $(\mathrm{bp})$ & $\begin{array}{l}\text { Coordinates in the Samoa D genome* } \\
\text { (GenBank accession no. CP002374) }\end{array}$ \\
\hline IGR TP0085-TP0086 & deletion $(13 \mathrm{bp})$ & $94986-94998$ \\
TP0136 & insertion $(\sim 0,06 \mathrm{kbp})$ & $158205-158206$ \\
TP0326 & insertion $(15 \mathrm{bp})$ & $348027-348028$ \\
TP0865 & deletion $(\sim 25 \mathrm{bp})$ & $945694-945718$ \\
\hline
\end{tabular}

*positions of detected indels in the TEN Bosnia A genome are shown as coordinates thereof in the Samoa D genome (GenBank accession no. CP002374)

Table 7. Indels identified in the TEN Bosnia A strain when compared to other investigated TPA and TPE strains.

\section{Conclusions}

The genomes of 9 pathogenic treponemes including T. p. pallidum strains (Nichols, SS14, DAL-1 and Mexico A), T. p. pertenue strains (Samoa D, CDC-2 and Gauthier), the FribourgBlanc isolate and T. p. endemicum (Bosnia A) were analyzed using several approaches 
including whole genome fingerprinting and whole genome sequencing. Genome analyses revealed several important chromosomal loci suitable for diagnostic purposes including: i) syphilis-causing treponemes and their molecular typing, ii) yaws treponemes, and iii) bejel treponemes.

A sequencing-based typing scheme using simultaneous analysis of 3 loci (TP0136, TP0548 and $23 \mathrm{~S}$ rDNA genes) in the T. p. pallidum genome was also evaluated. In addition, amplification of $23 \mathrm{~S}$ rDNA locus and its subsequent restriction target analysis was used to detect mutations leading to macrolide resistance. The unique sequences in the investigated TP loci appear to combine independently with each other and also combine independently with the number of repetitions in the arp gene and restriction profiles of tprEGJ genes. Several genomic regions were found to differ between T. p. pallidum and T. p. pertenue strains and comprised indels ranging from $33 \mathrm{bp}$ in the TP0266 gene to $635 \mathrm{bp}$ in the tprF gene (TP0316). In all cases, the Fribourg-Blanc simian isolate showed changes similar to T. $p$. pertenue strains suggesting a close relationship to the pertenue subspecies. A partial genome analysis of T. p. endemicum strain, Bosnia A, showed, that this strain clustered with TPE strains, though more distantly than that of the Fribourg-Blanc isolate. The Bosnia A genome contained indels in at least 4 regions (ranging between 13 and $\sim 60 \mathrm{bp}$ ) that can be used to differentiate the bejel treponeme from both T. p. pallidum and T. p. pertenue strains.

\section{Acknowledgements}

The authors thank Dr. David Cox for providing several TPA and TPE type strains. The TEN Bosnia A strain was kindly provided by S. Bruisten. This work was supported by grants from the U.S. Public Health Service to G.M.W. (R01 DE12488 and R01 DE13759), and S.J.N. (R01 AI49252 and R03 AI69107) and by grants of the Grant Agency of the Czech Republic (310/07/0321), of the Ministry of Health of the Czech Republic (NT11159-5/2010), and the Ministry of Education of the Czech Republic (VZ MSM0021622415) to D.S.

\section{References}

Antal, G.M., Lukehart, S.A. \& Meheus, A.Z. (2002). The endemic treponematoses. Microbes and Infection, Vol.4, No.1, (January 2002), pp. 83-94, ISSN 1286-4579

Asiedu, K., Amouzou, B. \& Dhariwal, A. (2008). Yaws eradication: past efforts and future perspectives. Bulletin of the World Health Organization, Vol.86, No.7, (July 2008), pp. 499, ISSN 0042-9686

Bennett, S. (2004). Solexa Ltd. Pharmacogenomics, Vol.5, No.4, (June 2004), pp. 433-438, ISSN $1462-2416$

Brinkman, M.B., McKevitt, M. \& McLoughlin, M. (2006). Reactivity of antibodies from syphilis patients to a protein array representing the Treponema pallidum proteome. Journal of Clinical Microbiology, Vol.44, No.3, (March 2006), pp. 888-891, ISSN 00951137

Brinkman, M.B., McGill, M.A. \& Pettersson, J.T. (2008). A novel Treponema pallidum antigen, TP0136, is an outer membrane protein that binds human fibronectin. Infection and Immunity, Vol.76, No.5, (May 2008), pp. 1848-1857, ISSN 0019-9567

Cameron, C.E., Lukehart, S.A. \& Castro, C. (2000). Opsonic potential, protective capacity, and sequence conservation of the Treponema pallidum subspecies pallidum Tp92. The 
Journal of Infectious Diseases, Vol.181, No.4, (April 2000), pp. 1401-1413, ISSN 00221899

Centurion-Lara, A., Castro, C. \& Barrett, L. (1999). Treponema pallidum major sheath protein homologue TprK is a target of opsonic antibody and the protective immune response. The Journal of Experimental Medicine, Vol.189, No.4, (February 1999), pp.647-656, ISSN 0022-1007

Centurion-Lara, A., Castro, C. \& Castillo, R. (1998). The flanking region sequences of the 15$\mathrm{kDa}$ lipoprotein gene differentiate pathogenic treponemes. The Journal of Infectious Diseases, Vol.177, No.4, (April 1998), pp. 1036-1040, ISSN 0022-1899

Centurion-Lara, A., Castro, C. \& Shaffer, J.M. (1997). Detection of Treponema pallidum by a sensitive reverse transcriptase PCR. Journal of Clinical Microbiology, Vol. 35, No. 6, (June 1997), pp. 1348-1352, ISSN 0095-1137

Centurion-Lara, A., Godornes, C. \& Castro, C. (2000b). The tprK gene is heterogeneous among Treponema pallidum strains and has multiple alleles. Infection and Immunity, Vol.68, No.2, (February 2000), pp. 824-831, ISSN 0019-9567

Centurion-Lara, A., Molini, B.J. \& Godornes, C. (2006). Molecular differentiation of Treponema pallidum subspecies. Journal of Clinical Microbiology Vol.44, No.9, (September 2006), pp. 3377-3380, ISSN 0095-1137

Centurion-Lara, A., Sun, E.S. \& Barrett, L.K. (2000a). Multiple alleles of Treponema pallidum repeat gene D in Treponema pallidum isolates. Journal of Bacteriology, Vol.182, No.8, (January 2000), pp. 2332-2335, ISSN 0021-9193

Flasarová, M., Šmajs, D. \& Matějková, P. (2006). Molecular detection and subtyping of Treponema pallidum subsp. pallidum in clinical specimens. Epidemiologie, mikrobiologie, imunologie, Vol.55, No.3, (August 2006), pp. 105-111, ISSN 1210-7913

Fraser, C.M., Norris, S.J. \& Weinstock, G.M. (1998). Complete genome sequence of Treponema pallidum, the syphilis spirochete. Science, Vol.281, No.5375, (July 1998), pp. 375-388, ISSN 0036-8075

Fribourg-Blanc, A., Mollaret, H.H. (1969). Natural treponematosis of the African primate. Primates in medicine, Vol.3, (n.d.), pp. 113-121

Gastinel, P., Vaisman, A. \& Hamelin, A. (1963). Study of a recently isolated strain of Treponema pertenue. La Prophylaxie sanitaire et morale., Vol.35, (July 1963), pp. 182-188

Giacani, L., Jeffrey, B.M. \& Molini, B.J. (2010). Complete genome sequence and annotation of the Treponema pallidum subsp. pallidum Chicago strain. Journal of Bacteriology, Vol.192, No.10, (May 2010), pp. 2645-2646, ISSN 0021-9193

Giacani, L., Sun, E.S. \& Hevner, K. (2004). Tpr homologs in Treponema paraluiscuniculi Cuniculi A strain. Infection and Immunity, Vol.72, No.11, (November 2004), pp. 65616576, ISSN 0019-9567

Gray, R.R., Mulligan, C.J. \& Molini, B.J. (2006). Molecular evolution of the tprC, D, I, K, G and $\mathrm{J}$ genes in the pathogenic genus Treponema. Molecular Biology and Evolution, Vol.23, No.11, (August 2006), pp. 2220-2233, ISSN 0737-4038

Grin, E.I. (1952). Endemic syphilis in Bosnia; clinical and epidemiological observations on a successful mass-treatment campaign. Bulletin of the World Health Organization, Vol.7, No.1, (n.d.), pp. 1-74, ISSN 0042-9686

Harper, K.N., Ocampo, P.S. \& Steiner, B.M. (2008a). On the origin of the treponematoses: a phylogenetic approach. PLoS Neglected Tropical Diseases, Vol.2, No.1, (November 2007), pp. e148, ISSN 1935-2735 
Harper, K.N., Liu, H. \& Ocampo, P.S. (2008b). The sequence of the acidic repeat protein (arp) gene differentiates venereal from nonvenereal Treponema pallidum subspecies, and the gene has evolved under strong positive selection in the subspecies that causes syphilis. FEMS Immunology and Medical Microbiology, Vol.53, No.3, (August 2008), pp. 322-332, ISSN 1574-695X

Liska, S.L., Perine, P.L. \& Hunter, E.F. (1982). Isolation and transportation of Treponema pertenue in golden hamsters. Current Microbiology, Vol.7, No.1, (n.d.), pp. 41-43, ISSN 0343-8651

Liu, H., Rodes, B. \& George, R. (2007). Molecular characterization and analysis of a gene encoding the acidic repeat protein (Arp) of Treponema pallidum. Journal of Medical Microbiology, Vol.56, No.6, (June 2007), pp. 715-721, ISSN 0022-2615

Livingstone, F.B. (1991). On the origin of syphilis: an alternative hypothesis. Current Anthropology, Vol.32, No.5, (December 1991), pp. 587-590, ISSN 0011-3204

Lukehart, S.A., Godornes, C. \& Molini, B.J. (2004). Macrolide resistance in Treponema pallidum in the United States and Ireland. New England Journal of Medicine, Vol.351, No.2, (July 2004), pp. 154-158, ISSN 0028-4793

MacDougall, J. \& Saint Girons, I. (1995). Physical map of the Treponema denticola circular chromosome. Journal of Bacteriology, Vol.177, No.7, (April 1995), pp. 805-811, ISSN 0021-9193

Margulies, M., Egholm, M. \& Altman, W.E. (2005). Genome sequencing in microfabricated high-density picolitre reactors. Nature, Vol.437, No.7057, (September 2005), pp. 376380, ISSN 0028-0836.

Marra, Ch.M., Sahi, S.K. \& Tantalo, L.C. (2010). Enhanced molecular typing of Treponema pallidum: geographical distribution of strain types and association with neurosyphilis. Journal of Infectious Diseases, Vol.202, No.9, (May 2010), pp. 13801388, ISSN 0022-1899

Matějková, P., Strouhal, M. \& Šmajs, D. (2008). Complete genome sequence of Treponema pallidum ssp. pallidum strain SS14 determined with oligonucleotide arrays. BMC Microbiology, Vol.8, No.1, (n.d.), pp. 76, ISSN 1471-2180

Matějková, P., Flasarová, M. \& Zákoucká, H. (2009). Macrolide treatment failure in a case of secondary syphilis: a novel A2059G mutation in the 23S rRNA gene of Treponema pallidum subsp. pallidum. Journal of Medical Microbiology, Vol.58, No.6, (June 2009), pp. 832-836, ISSN 0022-2615

McKevitt, M., Patel, K. \& Šmajs, D. (2003). Systematic cloning of Treponema pallidum open reading frames for protein expression and antigen discovery. Genome Research, Vol.13, No.7, (July 2003); pp. 1665-1674, ISSN 1088-9051

McKevitt, M., Brinkman, M.B. \& McLoughlin, M. (2005). Genome scale identification of Treponema pallidum antigens. Infection and Immunity, Vol.73, No.7, (July 2005), pp. 4445-4450, ISSN 0019-9567

Miao, R.M. \& Fieldsteel, A.H. (1980). Genetic relationship between Treponema pallidum and Treponema pertenue, two noncultivable human pathogens. Journal of Bacteriology, Vol. 141, No. 1, (n.d.), pp. 427-429, ISSN 0021-9193

Mikalová, L., Strouhal, M. \& Čejková, D. (2010). Genome analysis of Treponema pallidum subsp. pallidum and subsp. pertenue strains: Most of the genetic differences are localized in six regions. PLoS One, Vol.5, (December 2010), pp. e15713, ISSN 19326203 
Nichols, H.J. \& Hough, W.H. (1913). Demonstration of Spirochaeta pallida in the cerebrospinal fluid. Journal of the American Medical Association,Vol.60, No.2, (n.d.), pp. 108-110, ISSN 0002-9955

Pillay, A., Liu, H. \& Chen, C.Y. (1998). Molecular subtyping of Treponema pallidum subspecies pallidum. Sexually Transmitted Diseases, Vol.25, No.8, (September 1998), pp. 408-414, ISSN 0148-5717

Seshadri, R., Myers, G.S.A. \& Tettelin, H. (2004). Comparison of the genome of the oral pathogen Treponema denticola with other spirochete genomes. PNAS, Vol.101, No.15, (April 2004), pp. 5646-5651, ISSN 0027-8424

Šmajs, D., McKevitt, M. \& Wang, L. (2002). BAC library of T. pallidum DNA in E. coli. Genome Research, Vol.12, No.3, (March 2002), pp. 515-522, ISSN 1088-9051

Šmajs, D., McKevitt, M. \& Howell, J.K. (2005). Transcriptome of Treponema pallidum: gene expression profile during experimental rabbit infection. Journal of Bacteriology, Vol.187, No.5, (March 2005), pp. 1866-1874, ISSN 0021-9193

Šmajs, D., Matějková, P. \& Woznicová, V. (2006). Diagnosis of syphilis by polymerase chain reaction and molecular typing of Treponema pallidum. Reviews in Medical Microbiology, Vol.17, No.4, (December 2006), pp. 93-100, ISSN 0954-139X

Šmajs, D., Zobaníková, M. \& Strouhal, M. (2011). Complete genome sequence of Treponema paraluiscuniculi, strain Cuniculi A: the loss of infectivity to humans is associated with genome decay. PLoS One, Vol.6, No.5, (May 2011), pp. e20415, ISSN 1932-6203

Smibert, R.M. (1984). Genus III: Treponema Schaudinn 1905, 1728AL, In: Bergey's Manual of Systematic Bacteriology, Krieg, N.R. \& Holt, J.G., (Ed.), pp. 49-57, Williams\&Wilkins, ISBN 0683041088, Baltimore, MD, USA

Smith, J.L. (1971). Neuro-ophthalmological study of late yaws. I. An introduction to yaws. British Journal of Venereal Diseases and Genitourinary Medicine, Vol.47, No.4, (January 1971), pp. 223-225

Smith, J.L., David, N.J. \& Indgin, S. (1971). Neuro-ophthalmological study of late yaws and pinta. II. The Caracas project. British Journal of Venereal Diseases and Genitourinary Medicine, Vol.47, No.4, (January 1971), pp. 226-251

Stamm, L.V., Kerner, T.C. Jr \& Bankaitis, V.A. (1983). Identification and preliminary characterization of Treponema pallidum protein antigens expressed in Escherichia coli. Infection and Immunity, Vol.41, No.2, (August 1983), pp. 709-721, ISSN 0019-9567

Stamm, L.V. \& Bergen, H.L. (2000). A point mutation associated with bacterial macrolide resistance is present in both $23 \mathrm{~S}$ rRNA genes of an erythromycin-resistant Treponema pallidum clinical isolate. Antimicrobial Agents and Chemotherapy, Vol.44, No.3, (Marz 2000), pp. 806-807, ISSN 0066-4804

Strouhal, M., Šmajs, D. \& Matějková, P. (2007). Genome differences between Treponema pallidum subsp. pallidum strain Nichols and T. paraluiscuniculi strain Cuniculi A. Infection and Immunity, Vol.75, No.12, (December 2007), pp. 5859-5866, ISSN 00199567

Titz, B., Rajagopala, S.V. \& Goll, J. (2008). The binary protein interactome of Treponema pallidum-the syphilis spirochete. PLoS One, Vol.3, No.5, (May 2008), pp. e2292, ISSN 1932-6203

Turner, T.B. \& Hollander, D.H. (1957). Biology of the treponematoses based on the studies carried out at the International Treponematosis Laboratory Center of the Johns 
Hopkins University under the auspices of the World Health Organization. Monograph Series of the World Health Organization, Vol.35, pp. 3-266, ISSN 0512-3038

Van Damme, K., Behets, F. \& Ravelomanana, N. (2009). Evaluation of azithromycin resistance in Treponema pallidum specimens from Madagascar. Sexually Transmitted Diseases, Vol.36, No.12, (December 2009), pp. 775-776, ISSN 0148-5717

Walker, E.M., Howell, J.K. \& You, Y. (1995). Physical map of the genome of Treponema pallidum subsp. pallidum (Nichols). Journal of Bacteriology, Vol.177, No.7, (April 1995), pp. 1797-1804, ISSN 0021-9193

Weinstock, G.M., Norris, S.J. \& Sodergren, E. (2000). Identification of virulence genes in silico: infectious disease genomics, In: Virulence mechanisms of bacterial pathogens, Brogden, K.A., Roth, J.A., Stanton, T.B., Bolin, C.A., Minion, F.C., Wannemuehler, M.J., (Ed.), 251-261, ASM Press, ISBN 1-55581-174-4, Washington, DC, USA

Wendel, G.D., Jr, Sanchez, P.J. \& Peters, M.T. (1991). Identification of Treponema pallidum in amniotic fluid and fetal blood from pregnancies complicated by congenital syphilis. Obstetrics and Gynecology, Vol.78, No.5, (November 1991), pp. 890-894, ISSN 00297844 


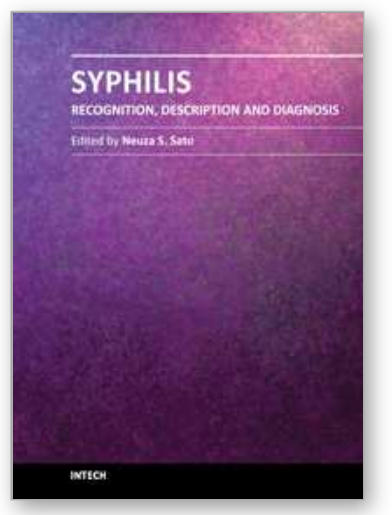

\author{
Syphilis - Recognition, Description and Diagnosis \\ Edited by Dr. Neuza Satomi Sato
}

ISBN 978-953-307-554-9

Hard cover, 130 pages

Publisher InTech

Published online 21, November, 2011

Published in print edition November, 2011

Syphilis, a sexually transmitted disease was first described in 15th century, is caused by Treponema pallidum subsp. pallidum and occurs worldwide. This book is a collection of chapters presenting the novel knowledge about the T. pallidum and some historical and up to date information about venereal disease and syphilis. The collection of articles includes: immunological aspects recognition of $T$. pallidum by the pattern recognition receptors of the innate immune; the whole genome analysis of treponemes and new targets for its molecular diagnosis; some historical aspects of venereal diseases treatment; natural history of syphilis including clinical manifestation and epidemiology; a clinical aspects dealing with psychiatric manifestations of neurosyphilis; spatial and temporal patterns of primary syphilis and secondary syphilis described by the spatial and spacetime scan statistics; a commonly used methods for laboratorial diagnosis, the serological response to treatment of syphilis and safety in blood transfusion. I hope this book will be useful for students and research fellows as well for the wide audience.

\title{
How to reference
}

In order to correctly reference this scholarly work, feel free to copy and paste the following:

David Smajs, Lenka Mikalová, Darina Cejková, Michal Strouhal, Marie Zobanîková, Petra Pospišilová, Steven J. Norris and George M. Weinstock (2011). Whole Genome Analyses of Treponemes: New Targets for Strainand Subspecies-Specific Molecular Diagnostics, Syphilis - Recognition, Description and Diagnosis, Dr. Neuza Satomi Sato (Ed.), ISBN: 978-953-307-554-9, InTech, Available from:

http://www.intechopen.com/books/syphilis-recognition-description-and-diagnosis/whole-genome-analyses-oftreponemes-new-targets-for-strain-and-subspecies-specific-molecular-diagnos

\section{INTECH}

open science | open minds

\section{InTech Europe}

University Campus STeP Ri

Slavka Krautzeka 83/A

51000 Rijeka, Croatia

Phone: +385 (51) 770447

Fax: +385 (51) 686166

www.intechopen.com

\section{InTech China}

Unit 405, Office Block, Hotel Equatorial Shanghai

No.65, Yan An Road (West), Shanghai, 200040, China

中国上海市延安西路65号上海国际贵都大饭店办公楼405单元

Phone: +86-21-62489820

Fax: +86-21-62489821 
(C) 2011 The Author(s). Licensee IntechOpen. This is an open access article distributed under the terms of the Creative Commons Attribution 3.0 License, which permits unrestricted use, distribution, and reproduction in any medium, provided the original work is properly cited. 